\title{
Legal Regulation of Waste Management in Ukraine on the Way to European Integration
}

\author{
By Serhii Kidalov ${ }^{1}$, Vitaliy Vitiv ${ }^{2}$, Liudmyla Golovko ${ }^{3}$, Viktor Ladychenko ${ }^{4}$
}

\begin{abstract}
The article is devoted to the research of problems of adaptation of Ukrainian legislation to the norms of EU law. The environmental well-being of the population depends on the legal regulation of waste management and the role of government agencies in controlling these activities. Particular attention in this scholarly work is paid to the overriding objective of learning from the experience of the EU member states by creating a qualitative mechanism and achieving the main result improvement of national legislation by implementing European standards in the sphere of waste management.
\end{abstract}

Keywords: EU waste policy, EU law, waste management, municipal waste, adaptation of Ukrainian legislation to EU law.

\section{Legal Regulation of Waste Management in Ukraine}

Nowadays, a significant number of legal acts have been adopted in Ukraine, in particular the Laws of Ukraine: "On Waste"; "On Environmental Protection", "On Ensuring Sanitary and Epidemiological Well-Being of the Population"; "On the management of radioactive waste"; "On Scrap Metal"; "On High Risk Objects"; Order of the Ministry of Housing and Communal Services of Ukraine "On Approval of the Rules for the Operation of Landfills of Household Waste", Subsoil Code, etc. This list is not exhaustive, as there are other by-laws, normative legal acts adopted by bodies of local self-government, which though exist, but observance of which is not carried out.

According to Article 16 of the Constitution of Ukraine, the necessity of ensuring environmental safety and maintaining the ecological balance in the territory of Ukraine, overcoming the consequences of the Chornobyl catastrophe - a catastrophe of planetary scale, preserving the gene pool of the Ukrainian people are a duty of the state. According to the decree of the Cabinet of Ministers of Ukraine № 820-r of 08.11.2017, the National Strategy of Waste Management in Ukraine until 2030 is approved, which is aimed at the necessity of solving a critical situation that has arisen with the generation, accumulation, storage, processing, utilization and disposal of waste, development of environmental threats.

| ${ }^{1} \mathrm{PhD}$., associate professor of the Department of International Law and Comparative Law of the National University of Life and Environmental Sciences of Ukraine.

${ }^{2} \mathrm{PhD}$., assistant of the Department of International Law and Comparative Law of the National University of Life and Environmental Sciences of Ukraine.

${ }^{3} \mathrm{PhD}$., associate professor of the Department of International Law and Comparative Law of the National University of Life and Environmental Sciences of Ukraine.

${ }^{4}$ Doctor of Juridical Science, professor, head of the Department of International Law and Comparative Law of the National University of Life and Environmental Sciences of Ukraine. 
The Law of Ukraine "On Environmental Protection", in particular, Article 55 contains obligations for the subjects of ownership of waste, which must take effective measures to reduce the amount of waste generation, as well as measures for their recycling and disposal. The Law of Ukraine "On Waste" defines the basic principles of state policy on waste, namely: ensuring the collection and disposal of waste; minimizing waste generation; organization of control over the placement of waste etc. The law introduced a number of necessary changes. Thus, according to the law, the incineration of household waste in Ukraine is allowed only for energy purposes in order to produce thermal and / or electrical energy. It is prohibited to design, construct and operate landfills for domestic waste without equipping groundwater protection systems and neutralizing biogas. These changes to the legislation in Ukraine were extremely necessary. However, the disadvantage is that the requirements of the new legislation are not being implemented in practice (Golovko, 2017; Krasnova, 2019; Ladychenko, 2018).

According to the order "On Approval of Methodological Recommendations for Cleaning the Territories of Settlement" approved by the Ministry of Housing and Communal Services of Ukraine № 213 of 07.07.2008, Ukraine provides for a system of collection and removal of solid and liquid household waste. At the same time, a number of serious shortcomings remain in the state of sanitation and waste management in towns and cities: there is no single, clearly articulated concept for integrated waste management (Ladychenko, 2013); exhausted landfill capacity; unsatisfactory technological parameters and the level of efficiency of use of the system of collection and removal of various wastes, which also do not take into account the specifics and capabilities of the organization of selective collection, storage, processing and disposal of waste; there are no regional regulatory documents defining the system of work with different waste at the local level; there is no start-up capital and financial and economic opportunities to support businesses and organizations of various forms of ownership in ordering the sanitation of the city and attracting the most effective waste management schemes. Technical policy does not contribute to reducing the amount of waste coming to landfill, contradicts world practice and does not meet the interests of the population of large cities in all regions of Ukraine. Almost all household waste is stored in landfills. The vast majority of them operate in congestion mode, that is, in violation of state regulations for the volume of waste accumulation. At the same time, landfills are a source of intense pollution of the atmosphere and groundwater. Almost in none of them the filtrates are removed. Almost all landfills require immediate sanitation and recultivation. The problem of creation of new landfills is not resolved. Half of the household waste landfill receives industrial waste. In addition, the process of creating unauthorized municipal waste dumps is ongoing in many villages and towns. It is quite difficult to develop a balanced economic and planning policy of administrative and legal management in the field of sanitary cleaning of the city that takes into account the interests of all parties. But it is necessary to strive for this, in view of the interconnectedness of all aspects of waste management from the standpoint of environmental engineering, economics and energy-saving technologies (Rybalkova, 2016).

Also, the State Enterprise for Managing Waste as Secondary Raw Materials was established in Ukraine. The creation of this enterprise was necessary because annually, 
about 13 million tonnes of municipal solid waste is generated in Ukraine, including 4 million tonnes of used packaging, which together with other constituent solid waste is stored at 4469 landfills and dumps, of which $314(7 \%)$ are overloaded and 897 (20\%) do not meet environmental safety requirements (Ministry of Development..., 2020). The State Enterprise for Managing Waste as Secondary Raw Materials shall provide for the organization of a system for the collection, preparation and disposal of used packaging, packaging materials and waste as secondary raw materials. However, the company does not cope with the functions assigned to it.

The dominant way of managing household waste in Ukraine is its removal and disposal at landfills and dumps. According to expert estimates, more than 99 percent of landfill do not meet European requirements (Council Directive 1999/31/EC of 26.04.1999 "On the disposal of waste"). As a rule, due to insufficient level of control and lack of a proper system of household waste management, according to official data, more than 27 thousand unauthorized landfills are generated annually. Work on certification, land reclamation and rehabilitation of landfills is not being carried out properly (Zicha, 2019). Norms of European law, in particular EU Waste Framework Directive (Directive 2008/98/EC of 19 November 2008), Council Directive 91/689 EEC on Hazardous Waste; Council Directive 1999/31/EC of 26 April 1999 on the landfill of waste; Directive 2010/75/EU of the European Parliament and of the Council of 24 November 2010 on industrial emissions (integrated pollution prevention and control) clearly delineate the main instruments of waste management, such as the obligation to treat waste in such a way that it does not adversely affect the environment or human health, promote the use of the waste hierarchy and, in accordance with the "polluter pays" principle requirement for payment for waste disposal by the owner of the waste, previous owners or producers of the product after which the waste is left.

EU Environmental policy and law and its implementation in Ukraine have been the subject of research by many scientists (Funta, 2016; Golovko, 2019; Gulac, 2019; Kachur, 2020; Klimek, 2017; Ladychenko, 2019; Shkurti, 2019; Shulga, 2020; Yara, 2018,). Ukrainian legislation needs to be adjusted in line with EU law in order to implement environmental standards of waste management to the level of EU member states. That is, there is the need to adapt national legislation to the main EU environmental directives and to introduce higher-sanctioned norms of responsibility of officials who are empowered to exercise control in this sphere, to establish a system of public control over violations in the sphere of collection and disposal of waste and to improve environmental education of population.

\section{Legal Regulation of the Waste of Electrical and Electronic Equipment}

In order to remove obstacles to the use of waste, in particular electrical and electronic equipment, there is a need for a qualitative demarcation of a certain classification of this waste by their terminological characteristics and conceptual interpretation. In the European Union the rules of law regulate and establish certain classifications of electronic waste. Ukraine should use the experience of the EU as an example and apply it in the norms of national law, by amending existing standards or creating new ones adapted to modern requirements of the time. Therefore, today's 
challenges of a society that has become global require concrete changes in the political course and the creation of strategic plans for effective state control, focusing on European standards and directives, as exemplary elements of improving the laws of Ukraine.

A priority area in the field of environmental safety is the prevention of environmental problems (Ladychenko, 2017; Vitiv, 2016). Therefore, the issue of clarity of the concept of electronic waste and its classification are important factors in preventing the negative consequences of improper management of such waste.

In foreign legislation and scientific literature, morally and physically outdated equipment of modern IT technologies is called waste of electrical and electronic equipment (hereinafter WEEE). In Ukraine, unlike in EU countries, there is no definition of the list of goods and products related to WEEE, there is no statistical record of the volume of their production and processing, and there is no legal basis for regulating the process of handling them. Lack of WEEE processing facilities, lack of collection schemes lead to their landfill with all the negative environmental consequences. The situation needs a systematic approach and a quicker solution. The main task is to create conditions for raising living standards by introducing a systematic approach to waste management at the state and local levels, overcoming an endless amount of waste, and enhancing the quality of recycling and the obligation to reuse it. Waste generated from maintenance, processing of raw materials of different origin, industries containing hazardous substances, including wastes of electrical and electronic equipment are the result of imperfect legal framework, lack of effective control, including accounting and reporting, and also a quality waste management system. Overcoming this problem is important in the rapid development of electronic resources and energy infrastructure of the state (Kidalov, 2019).

The Tax Code of Ukraine occupies a significant place among the regulatory acts governing the disposal of WEEE. Thus, it determines the rates of tax for the disposal of waste in specially designated places or facilities. Instruction on filling in the reporting form "Report on the management of solid household waste", approved by the order of the Ministry of Construction; of Architecture and Housing and Communal Services of Ukraine in coordination with the State Statistics Committee attributes WEEE to mixed solid waste, which does not meet European standards. Accordingly, despite the large number of laws, by-laws, instructions, strategies, methodological recommendations in the sphere of waste management in Ukraine

conservation, recovery and sustainable use of electronic and electrical raw material waste remains low.

In the European Union management of WEEE is regulated by the following legal acts: Directive 2012/19/EU of the European Parliament and of the Council of 4 July 2012 on waste electrical and electronic equipment, Directive 2006/66/EC of the European Parliament and of the Council of 6 September 2006 on batteries and accumulators and waste batteries and accumulators and repealing Directive 91/157/EEC, Commission Regulation (EU) No 1103/2010 of 29 November 2010 establishing, pursuant to Directive 2006/66/EC of the European Parliament and of the Council, rules as regards capacity labelling of portable secondary (rechargeable) and automotive batteries and accumulators, Comission Decision of 29 September 2008 establishing a common 
methodology for the calculation of annual sales of portable batter, Commission Regulation (EU) No 493/2012 of 11 June 2012 laying down, pursuant to Directive 2006/66/EC of the European Parliament and of the Council, detailed rules regarding the calculation of recycling efficiencies of the recycling processes of waste batteries and accumulators.

The purpose of the Directive 2012/19/EU on waste electrical and electronic equipment is to establish measures for the protection of the environment and human health by preventing or reducing the adverse effects of the generation and management of waste electrical and electronic equipment. According to the Directive, from 2019, the minimum collection rate to be achieved annually shall be $65 \%$ of the average weight of EEE placed on the market in the three preceding years in the Member State concerned, or alternatively $85 \%$ of WEEE generated on the territory of that Member State. In accordance with Article 5 of this Directive, Member States are required to establish a separate collection system that will allow end-users to return electronic waste at least free of charge and to ensure the availability and availability of the necessary collection facilities, taking into account population density. Collection of used small electrical and electronic products (no external dimension more than $25 \mathrm{~cm}$ ) must be provided free of charge by distributors in retail stores selling electrical and electronic equipment with a defined area (at least $400 \mathrm{~m} \mathrm{2}$ ) and does not bind the end-users to buy equipment of equivalent type, unless an assessment shows that alternative existing collection schemes are likely to be at least as effective.

In most EU countries, distributors are physically and financially responsible for the collection of e-waste. At the same time, it should be emphasized that the role of the consumer in the value chain of preserving material in the economic system for as long as possible is significant enough. It is difficult to overestimate the consumer's contribution to ensuring the material's multiple rotation and extension of the product life cycle, as it is both the buyer and the user of the product, as well as the "owner" of the waste that needs to be disposed of properly. In order to realize the financial and physical responsibility of the manufacturer / distributor, that is, the obligation to collect the waste and to finance the process of handling it, the manufacturer reserves the right of ownership of the product it produces when it goes into the care category. At the same time, for the proper return of electronic waste by the user, it is necessary to create convenient and sufficient infrastructure and create economic incentives (Scientific work..., 2020).

On the example of the EU in Ukraine distributors supplying EEE to end consumers should have to provide free of charge WEEE collection for consumers (it may take many forms). Another proposal is that manufacturers should be able to introduce a depository system for EEE, the essence of which is that part of the money paid by the consumer for the equipment first goes to storage, and then returned to the consumer in exchange for waste of previously purchased equipment.

\section{Improvement of Economic Instrument of Waste Management at the Regional Level}


Economic mechanisms for sustainable environmental management and protection of the environment are considered to be more effective management tools than administrative, legal and other methods affecting the environmental worldview and human behavior. The structure of the regional economic management mechanism in the area of municipal waste management at the regional level presupposes the presence of targeted actions that follow from the general goals of the management system, forms of their implementation, levers of state regulation, instruments of implementation, functions and respective measures. A characteristic feature of the modern waste management system in Ukraine in general, and solid municipal waste in particular, is the predominance of administrative methods over economic ones. However, the experience of EU countries shows that only economic instruments can create leverage for such dispersed pollutants as household waste, vehicles, used packaging, etc. One of the methods of stimulating the use of waste and secondary resources in industrial production and the development of the secondary resources market may be incentive measures for enterprises, that is, reduction of the tax burden, preferential rates or not taxing the income derived from the use of waste or secondary resources in the production process (Maley, 2013).

There are several dozen sorting lines in Ukraine. However, the profits from the sale of sorted raw materials do not usually cover the cost of the waste sorting process. After all, the deeper the sorting is, the more expensive this process is. It is possible to significantly reduce the cost of waste recycling provided that the residents will sort it themselves. In some European countries, residents are financially encouraged to do so. For example, in Germany, Finland and some other countries in Europe special machines are installed where plastic bottles can be handed over and money received. Usually, the cost of the drink already includes the cost of recycling a plastic bottle. Ukraine should adopt this experience (Ladychenko, 2015).

Ilyinets community of Vinnytsia region has also good experience. The local government has found an original way to encourage residents to sort the waste - all the proceeds from the sale of recyclable waste are spent on greening of the city. Thus, residents see a direct link between the sorting of waste and the change in the appearance of the city. The city also approved a program for separate collection of solid household waste, which requires separation from the total mass of plastic bottles and plastic. For this purpose, in addition to the usual waste cans, the city authorities purchased about 150 special, lattice ones, intended for collection of plastic. It is interesting that the city did not buy the waste press, which costs about UAH 20000 (EUR 683) at its own expense. This equipment was rented for only UHR 1 (EUR 0.03) per month from the company that buys the raw material - LLC "Beautiful bottle". Residents have been actively involved in the waste sorting process, as they have understood the direct link between waste sorting and greening of the city - the proceeds from the sale of secondary plastic are spent on seedlings (Waste can be turned into money..., 2017).

Also, an important component of improving the economic tools in the area of solid municipal waste management is the provision of information and explanatory work among the local population, on the effective operation of the system of separate collection. Based on the experience of EU member states, municipalities should be involved in the implementation of regional environmental education strategies. 
Integration of waste prevention into school education must be accomplished (Methodology ..., 2016). It will increase the level of culture of the population in relation to the use of domestic waste. It is also necessary to develop and implement the projects aimed at waste prevention (The RE-NAB project, 2016; Retro things, 2019), which create opportunity to reuse old but functional things (Ladychenko, 2020). These changes could improve the field of waste management in Ukraine.

\section{Conclusions}

The problem of environmental pollution in Ukraine has become particularly relevant in the current context, as waste reuse and disposal is at a low technological level and low level of legal regulation. Anthropogenic pressure on the natural environment is the result of non-controllability on the part of the state and a lack of public awareness of the reality of the threat. To create a country's environmental protection, it is necessary to have 2 factors: the environmental consciousness of people and the influence of power structures. But for this it is necessary to create a legal framework with the help of which both the person and public authorities can see the motivation: both a real threat of punishment for a breach of legislation and encouragement. According to annex XXX to chapter 6 of the Association Agreement, Ukraine undertakes to gradually approximate its legislation to the EU legislation on waste and resource management within the agreed time frame (related to the date the Association Agreement came into force). The full implementation of the commitments requires full adaptation of the legal principles of solid waste management to the requirements of the European Union. The main goal should be to increase the sorting and recycling of waste, to move away from landfilling and fulfillment of mandatory European targets.

\section{References}

Funta, R., Golovko, L., Juriš, F. (2016). Európa a európske právo. Bratislava: Iris.

Golovko, L. (2017) Implementation of EU Water Policy in Ukraine: Problems and Perspectives. Proceedings of the $8^{\text {th }}$ International Scientific Conference Rural Development, 605-610.

Golovko, L. (2019). Adaptation of Ukrainian Legislation to EU Law in the Field of Food Safety, Proceedings of the International Conference on European Dimensions of Sustainable Development, April 23-24, 2019. - Kyiv: NUFT, 60-61.

Golovko, L. (2019). Legal Regulation of Food Security, Human. Law. Environment, Volume 10, № 1, $128-133$.

Golovko, L., Yara, O., Kutsevych, M., Hubanova, T. (2019). Environmental Policy Integration in Ukraine and the EU. European Journal of Sustainable Development, Volume 8, № 3, 221-227.

Gulac, O., Dubchak, L., Iarmolenko, I., Yanchuk, J. (2019). Cooperation of Ukraine and the European Union in the ecological sector: directions and prospects. European Journal of Sustainable Development, Volume 8, № 1, 22-30.

Kachur, V., Protosavitska, L., Zasukha, L., Golovko L. (2020). The Role of Legal Culture in Maintaining Social Stability and Countering Separatist Movements: Case of Ukraine. European Journal of sustainable development, Volume 9, № 1, 294-299.

Kidalov S. (2019). Legal regulation of waste management of electronic and electrical equipment. South Ukrainian Law Journal, 3, 131-134.

Kidalov, S. (2019). Definition of the legal classification of electrical and electronic waste in the European Union: experience for Ukraine, Young Scientist, 11, 322-325.

Kidalov, S. (2019). State of adaptation of national legislation to European Union law in the field of waste management, Law. Human. Environment, 10 (14), 174 - 179. 
Klimek, L. (2017). Mutual Recognition of Judicial Decisions in European Criminal Law. Cham: Springer.

Krasnova, Yu.A., Deineha, M.A., Honcharuk, L.Yu., Svyatchenko, L.O. (2019). Ecological court as the guarantee of protection of rights of human and citizens. Bulletin of NAS RK, № 4, 185-191

Ladychenko, V. (2007). Humanistic foundations of the organization of state power: a monograph. Kyiv: Kyiv National University of Trade and Economics.

Ladychenko, V. (2015). The Place of the Right to Drinking Water in the Human Rights System. Scientific Notes of the International Humanities University, 23, 62-65.

Ladychenko, V., Golovko L. (2018). The Right to Access to Environmental Information in Ukraine and the EU. European Journal of sustainable development, Volume 7, № 3, 455-459.

Ladychenko, V., Golovko, L. (2013). Legal Regulation of the Common Agricultural Policy in the EU. International Scientific Electronic Journal Earth Bioresources and Quality of Life, 3. Retrieved from: http://www.gchera-ejournal.nubip.edu.ua/index.php/ebql/article/view/102

Ladychenko, V., Golovko, L. (2015). Legislative support for drinking water supply in the United States. Scientific Notes of the Institute of Legislation of the Verkhovna Rada of Ukraine, 5, 39-43.

Ladychenko, V., Golovko, L. (2017). Implementation of European Environmental Policy in Ukraine: Problems and Prospects. European Journal Of Sustainable Development, Volume 6, Issue 3, 333-339

Ladychenko, V., Golovko, L. (2019). Achieving sustainable development through environmental accounting and disclosure of environmental information: experience of Ukraine and the EU. Sustainable development under the conditions of European integration: collective monograph, Ljubljana, Slovenia. Part II., p.182-194.

Ladychenko, V., Golovko, L., Kapplová, O. (2019). Municipality as Regulator of Household waste Management. Scientific Papers of the Legislation Institute of the Verkhovna Rada of Ukraine, 5, 38-45.

Ladychenko, V., Maksymenko, Yu. (2019). Chiefs as officials of the system of local self-government in Ukraine: historical and legal aspect. Scientific notes of the Institute of Legislation of the Verkhorna Rada of Ukraine, 2, 8-18.

Ladychenko, V., Melnychuk, O., Golovko, L., Burmak, O. (2020). Waste Management at the Local Level in the EU and Ukraine. European Journal of Sustainable Development, Volume 9, № 1, 329-329.

Ladychenko, V., Melnychuk, O., Yara, O., Kanaryk J. (2019). International Mechanism of the Environmental Information Access and Cooperation Framework for Climate Change Protection. European Journal of Sustainable Development, Volume 8, № 4, 131-139.

Ladychenko, V., Yara, O., Golovko, L., Serediuk, V. (2019). Groundwater Management in Ukraine and the EU. European Journal of Sustainable Development, Volume 8, Issue 1, 31-39

Ladychenko, V., Yara, O., Uliutina, O., Golovko, L. (2019). Environmental Liability in Ukraine and the EU. European Journal of Sustainable Development, Volume 8, № 2, 261-267.

Ladychenko, V., Yemelyanenko, K. (2018). Formation of Executive Committees of United Territorial Communities. Scientific Notes of the Institute of Legislation of The Verkhovna Rada of Ukraine, 5, 14-20.

Maley, O. (2013). Improvement of economic instrument of management by the sphere of handling municipal by wastes in a regional level. Effective Economy, 12. Retrieved from: http:/ / www.economy.nayka.com.ua/?op $=1 \& z=2567$

Methodology for the integration of waste prevention into teaching for individual school levels and afterschool education. (2016). Retrieved from: https://www.mzp.cz/C1257458002F0DC7/cz/program_predchazeni_vzniku_odpadu/\$FILE/O ODP-metodika_vzdelavani-20170201.pdf

Ministry of Development of Communities and Territories of Ukraine. Status of the sphere of household waste management in Ukraine in 2019. (2020). Retrieved from: https://www.minregion.gov.ua/napryamki-diyalnosti/zhkh/terretory/stan-sfery-povodzhennyaz-pobutovymy-vi/

Retro things. (2019). Retrieved from: https://www.retro-use.cz/

Rybalkova, O. (2016). Waste Management. Kharkiv: NUCZU.

Scientific work "Construction of canvas business model for provision of reverse movement of electronic waste through the service of delivery of equipment at trade enterprises". (2020). Retrieved from: http://odeku.edu.ua/wp-content/uploads/Reversnij-potik.pdf

Shkurti, A. (2019). Analysis of the Western Balkans power market prices within the entso-e framework. European Journal of Sustainable Development, Volume 8, № 1, 229-236. 
Shulga, I., Kurylo, V., Gyrenko, I., Savych, S. (2019). Legal Regulation of Energy Safety in Ukraine and the European Union: Problems and Perspective. European Journal of Sustainable Development, Volume 8, № 3, 439-447.

The RE-NAB project will provide furniture to the socially needy. (2016). Retrieved from: https://www.brno.cz/brno-aktualne/tiskovy-servis/tiskove-zpravy/a/projekt-re-nab-zajistinabytek-socialne-potrebnym/

Vitiv, V. (2016). Information rights as part of the fourth generation of human rights, Scientific Papers of the Legislation Institute of the Verkhouna Rada of Ukraine, 5, 22-26.

Waste can be turned into money and flowers. Experience of the Illintsev community. (2017). Retrieved from: https://life.pravda.com.ua/projects/novi-gromadi/2017/10/25/227104/

Yara, O., Uliutina, O., Golovko, L., Andrushchenko, L. (2018). The EU Water Framework Directive: Challenges and Prospects for Implementation in Ukraine. European Journal of Sustainable development, Volume 7, № 2, 175-182.

Zicha, J., Golovko, L. (2019). Legislation of the European Union Related to Municipal Waste and its Reflection in the Association Agreement with Ukraine, Human. Law. Environment, Volume 10, № $14,180-186$. 